\title{
Assessment of the nervous system state in low birth weight children taking into account the FADS2 rs174583 (C/T) gene polymorphism
}

\author{
T. Ye. Shumna*A,E,F, T. O. Levchuk-Vorontsova ${ }^{\mathrm{B}, \mathrm{C}, \mathrm{D}}$
}

Zaporizhzhia State Medical University, Ukraine

A - research concept and design; B - collection and/or assembly of data; C - data analysis and interpretation; D - writing the article;

$\mathrm{E}$ - critical revision of the article; $\mathrm{F}$ - final approval of the article

Key words: alleles, genotypes, polyunsaturated fatty acids, preterm birth, children.

\section{Zaporozhye}

medical journal

2020; $22(5), 652-663$

*E-mail:

tshumnaya72@gmail. $\underline{\mathrm{com}}$
Aim. To assess the neurological status and index of neuropsychological development in low birth weight children taking into account the FADS2 rs174583 (C/T) gene polymorphism.

Materials and methods. To study the FADS2 rs174583 (C/T) gene polymorphism, 170 children were examined. The children were divided into 3 groups depending on their birth weight: group I included 53 children (birth weight was 1500-1999 g, gestation period - 33.0 [32.0; 35.0] weeks), group II included 77 children (birth weight - 2000-2499 g, gestation period - 35.0 [34.0; 36.0] weeks), group III was composed of 40 children as a control (birth weight - more than $2500 \mathrm{~g}$, gestation period - 38.0 [36.0; 39.0] weeks). The genotyping was carried out using a polymerase chain reaction method.

Results. The C allele and the C/T genotype frequencies of the FADS2 rs174583 gene polymorphism in the children matched those in North-Western Europe. Seizures in the past medical history due to the nervous system disorders were most commonly occurred in children with the TT genotype $(16.45 \%, P<0.05)$, while patients with the CC genotype had seizures in only $5.6 \%$ of cases. Children with a birth weight of 1500-1999 g carrying the C/T heterozygous genotype and the T/T homozygous genotype of the FADS2 (rs1745683) gene polymorphism had a lower total Apgar score than children with a birth weight of more than $2000 \mathrm{~g}$ $(P<0.05)$. The coefficient of psychomotor development was the lowest in children with birth weight of $1500-1999 \mathrm{~g}$ and the minor homozygous T/T genotype of the FADS2 (rs1745683) gene polymorphism, at 83.0 (75.0; 83.0), which corresponded to a weak normal level of the neuropsychiatric development, while the highest index of psychomotor development $(116.0(112.0 ; 141.0))$ and a normal high level of neuropsychiatric development were significantly registered in children with birth weight of $2500 \mathrm{~g}$ and the major homozygous $\mathrm{C} / \mathrm{C}$ genotype.

Conclusions. It is possible that the predominance of the homozygous $\mathrm{C} / \mathrm{C}$ genotype and the heterozygous $\mathrm{C} / \mathrm{T}$ genotype fulfils a protective function in order to reduce the negative effects of preterm birth on the nervous system.
Киючові слова: алельні гени, генотипи, поліненасичені жирні кислоти, передчасні пологи, Аіти.

Запорізький медичний журнал. 2020. T. 22, № 5(122) C. $652-663$

\section{Оцінювання стану нервової системи дітей, які народжені з низькою масою тіла, враховуючи поліморфізм C/T гена FADS2 (rs174583)}

\section{Т. Є. Шумна, Т. О. Аевчук-Воронцова}

Мета роботи - оцінити неврологічний стан та індекс нервово-психічного розвитку дітей, які народжені з низькою масою тіла, враховуючи поліморфізм C/T гена FADS2 (rs1745683).

Матеріали та методи. Для вивчення поліморфізму C/T гена FADS2 (rs174583) обстежили 170 дітей, яких поділили на 3 групи залежно від ваги під час народження: I група - 53 дитини із вагою під час народження 1500-1999 г, строком гестації - 33,0 [32,0;35,0] тижня; II група - 77 дітей із вагою під час народження 2000-2499 г, строком гестації 35,0 [34,0; 36,0] тижня; III група (контролю) - 40 дітей із вагою під час народження понад 2500 г, строком гестації - 38,0 [36,0; 39,0] тижня. Генотипування здійснили методом полімеразної ланцюгової реакції.

Результати. Частота виявлення алеля C поліморфізмом C/T гена FADS2 (rs174583) відповідає показникам південно-західної Європи. Ураження нервової системи, як-от судоми, частіше реєстрували в дітей із генотипом ТT $(16,45 \%, p<0,05)$, а в пацієнтів із генотипом СС судоми визначали в 5,6 \% випадків. Діти з масою тіла під час народження 1500-1999 г (гетерозиготи та гомозиготи за алелем ТT) мали вірогідно меншу суму балів за шкалою Апгар, ніж діти з вагою понад 2000 г $(p<0,05)$. Найнижчий коесріцієнт психомоторного розвитку визначили в дітей із масою тіла під час народження 1500-1999 г і мінорним гомозиготним генотипом TT поліморфрізму C/T гена FADS2 - 83,0 (75,0; 83,0); найвищий показник психомоторного розвитку $(116,0(112,0 ; 141,0))$ частіше реєстрували в дітей із масою тіла під час народження понад 2500 гі генотипом СС.

Висновки. Імовірно, переважання домінантного генотипу СС і гетерозиготного генотипу СТ відіграє протекторну функцію для зменшення негативного впливу з боку нервової системи, що пов'язаний із передчасним народженням.

\section{Оценка состояния нервной системы детей с низкой массой тела при рождении, учитывая полиморфизм C/T гена FADS2 (RS174583)}

\section{Т. Е. Шумная, Т. О. Аевчук-Воронцова}

Цель работы - оценить неврологическое состояние и индекс нервно-психического развития детей, родившихся с низкой массой тела, учитывая полиморфизм C/T гена FADS2 (RS174583).

Материалы и методы. Для изучения полиморфизма C/T гена FADS2 (rs174583) обследовали 170 детей. Детей поделили на 3 группы в зависимости от веса при рождении: I группа - 53 ребенка с весом при рождении 1500-1999 г, сроком 
гестации 33,0 [32,0; 35,0] недели; II группа - 77 детей с весом при рождении 2000-2499 г, сроком гестации 35,0 [34,0; 36,0] недели; III группа (контроля) - 40 детей с весом при рождении больше 2500 г и сроком гестации 38,0 [36,0; 39,0] недели. Генотипирование провели методом полимеразной цепной реакции.

Результаты. Частота обнаружения аллеля C полиморфизма C/T гена FADS2 (rs174583) приближалась к показателям северо-западной Европы. Поражение нервной системы в виде судорог чаще всего регистрировали у детей с генотипом ТT $(16,45 \%, p<0,05)$, а у пациентов с генотипом СС судороги отмечены только в 5,6 \% случаев. Дети с весом при рождении 1500-1999 г (и гетерозиготы, и гомозиготы по аллелю Т) имели достоверно более низкую оценку по шкале Апгар, чем дети с весом более 2000 г ( $p<0,05)$. Индекс психомоторного развития самый низкий у детей с массой тела при рождении 1500-1999 г с минорным гомозиготным генотипом гена FADS2 (rs1745683), составляя 83,0 (75,0; 83,0); самый высокий показатель индекса психомоторного развития $(116,0(112,0 ; 141,0))$ достоверно чаще регистрировали у детей с генотипом СС и массой тела при рождении более 2500 г.

Выводы. Вероятно, преобладание доминантного генотипа СС и гетерозиготного генотипа СТ имеет протекторную функцию для защиты нервной системы от негативного влияния, связанного с преждевременным рождением.

Nowadays, all over the world, regardless of the level of economic development of the states, there has been observed a steady tendency of the frequency increase of premature births and birth of babies with low birth weight [1-5]. Thus every tenth child is born prematurely, and according to some estimations, it makes about 15 million children annually, more than 1 million of which dies due to complications associated with premature birth [5].

The global indicator of premature birth cases ranges from $5 \%$ to $18 \%$. On average, $11.8 \%$ of births occur prematurely in low-income countries than in middle and high incomes countries where this figure is more than $9 \%(9.4 \%$ and $9.3 \%$ respectively). Over $60 \%$ of premature births occur in Africa and Asia. Premature birth is a global case for countries such as India, China, Nigeria, Pakistan, the USA, the Philippines, the Democratic Republic of the Congo, and Brazil. Unlike the above in the following 11 countries, the lowest frequency of premature birth is registered: Belarus, Ecuador, Latvia, Finland, Croatia, Samoa, Lithuania, Estonia, Antigua/Barbuda, Japan and Sweden [3-5].

In addition to the significant effect of premature births on mortality rates, in some cases, their after-effects can be observed throughout the child's future life, resulting in disturbances in the development and functioning of the nervous system due to an increased risk of cerebral palsy, learning disability, visual impairment, and affecting physical health in the long run due to the increased risk of non-infectious diseases [3,4,6-8]. All this falls most heavily on families, society and health care system $[3,4]$. Therefore, the maximum recovery and preservation of the health of prematurely born children is an urgent need of society.

In this regard, in May 2018, the 13th Congress of the International Society for the Study of Fatty Acids and Lipids "Arachidonic and Docosahexaenoic Acids in Infant Development" was held in the United States discussing the effects of polyunsaturated fatty acids on the health and development of children, including those born prematurely [6-8]. It is known that fatty acids play an important role in development both in the prenatal period and in the postnatal period. The balance of $n-3$ or $n-6$ long-chain polyunsaturated fatty acids can increase or weaken the effects of hypoxia, inflammation, infection, thrombosis and oxidative damage to key organs (lungs, brain and retina). Besides, n-3 and n- 6 polyunsaturated fatty acids are necessary for the normal structure and functions of central nervous system and development of sensory organs. These lipids generate eicosanoids that are modulators of oxidative damage, as well as poten- tial protectors of retina, cerebral cortex, pulmonary and vascular endothelium [10-25].

Provision of the body with active long chain polyunsaturated fatty acids depends not only on the intake of their precursors or directly the acids with food, but also on the activity of endogenous desaturase, which is genetically determined [22-25].

Fatty acid desaturase refers to enzymes that catalyze the conversion of a single bond between carbon atoms of fatty acid $(\mathrm{C}-\mathrm{C})$ into double bond $(\mathrm{C}=\mathrm{C})$. The resulting double bonds are called unsaturated bonds, and the enzymatic reactions are desaturation reactions. Polymorphisms in the fatty acid desaturase genes determine the effectiveness of the endogenous metabolism of polyunsaturated fatty acids [26,27].

Certain polymorphisms of the FADS2 gene are associated with a decrease in the incidence of bronchial asthma, atopic dermatitis, as well as possible disorders of the cognitive function [8-10]. For example, minor alleles of the FADS2 gene were associated with lower production of polyunsaturated fatty acids [27-29]. The identification of such gene variants that may modulate lipid levels is important for our understanding of the characteristics and development abnormalities in children.

\section{Aim}

Assess the neurological status and index of neuropsychological development of children with low birth weight taking into account the polymorphism of $\mathrm{C} / \mathrm{T}$ gene FADS2 (rs174583).

\section{Materials and methods}

To study the polymorphism of C/T gene FADS2 (rs174583), 170 children were examined. The children were divided into 3 groups depending on their weight at birth: group I included 53 children (weight at birth was 1500-1999, gestation period 33.0 [32.0; 35.0] weeks), group II - 77 children (weight at birth 2000-2499 g, gestation period 35.0 [34.0; 36.0] weeks), group III - 40 children constituting a control group (weight at birth more than $2500 \mathrm{~g}$, gestation period 38.0 [36.0; 39.0] weeks).At birth, all children were evaluated on the Apgar scale, and their neurological status was evaluated immediately after birth on ten neurological signs of the Dubovich scale, each of which was scored from 0 to 2 or from 0 to 5 . Subsequently, neuropsychic development was determined in the examined children after reaching the adjusted age of 12 months, using the Griffits-GES development scale with an
Киючевые слова: аммемьные гены, генотипы, полиненасыщенные жирные кислоты, преждевременные роды, Аети.

Запорожский медицинский журнал. 2020. T. 22, № 5(122) C. $652-663$ 
1

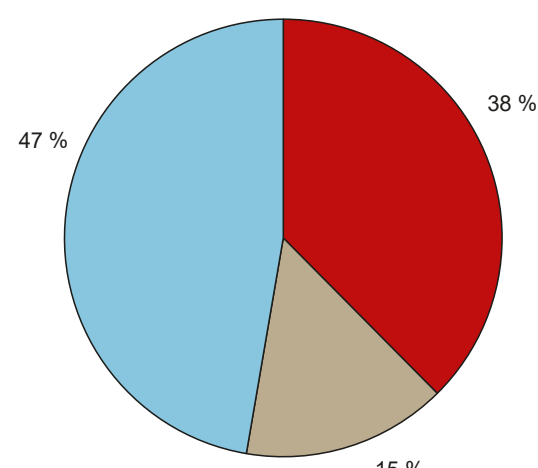

$15 \%$

3

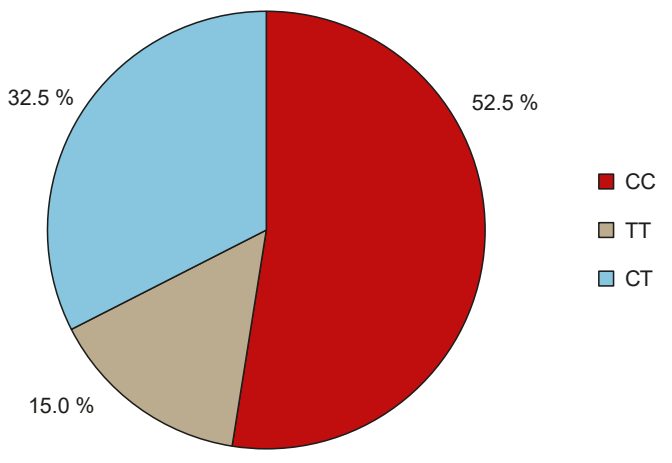

2

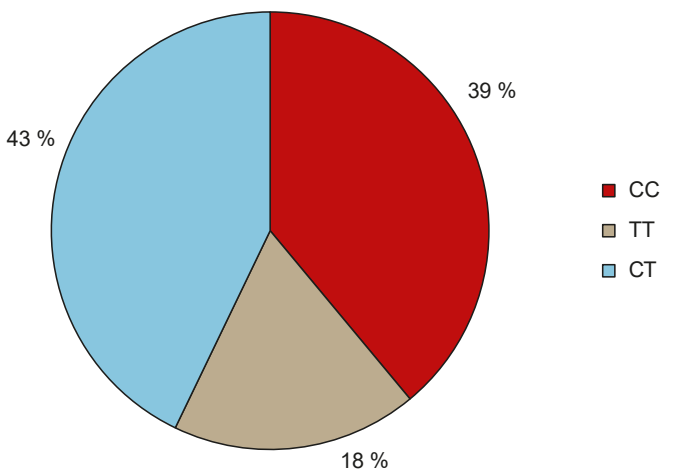

Fig. 1. Distribution of genotypes of the polymorphism of C/T gene FADS2 (rs174583) among children of the Group I.

*: significant difference between the groups, $\mathrm{P}<0.05$.

Fig. 2. Distribution of genotypes of the polymorphism of C/T gene FADS2 (rs174583) among children of the Group II.

*: significant difference between the groups, $\mathrm{P}<0.05$.

Fig. 3. Distribution of genotypes of the polymorphism of C/T gene FADS2 (rs174583) among children of the Group III.

*: significant difference between the groups, $P<0.05$. integrated evaluation of neuropsychic development (quolient development) and the determination of its QD coefficient. All indicators were analyzed taking into account the distribution of the diagnosed genotypes of $\mathrm{C} / \mathrm{T}$ polymorphism of the FADS2 gene (rs1745683) in the examined children.

The genotyping was carried out by polymerase chain reaction method in accordance with the instruction (Applied Biosystems, USA) using samples of total DNA recovered from whole venous blood with the "SNP-Screen" reagent kit (Syntol manufacturer) on the amplificator CFX96TM Real-Time PCR Detection Systems (Bio-Rad laboratories, Inc., USA). This research was carried out in the Division for Molecular Genetic Research of the Educational Medical Laboratory Center, Zaporizhzhia State Medical University. The work is carried out within the framework of the scientific research of the Department of Children's Diseases of the Zaporizhzhia State Medical University.

The obtained results of the frequencies distribution of alleles and genotypes of the gene under research were used to analyze the genetic structure of the population according to the Hardy-Weinberg principle. To compare the frequencies of alleles and genotypes in different groups, the non-parametric statistical method " $2 \times 2$ Table", the Chisquare $(\mathrm{df}=1)$ was used. Also, the odds ratio $(\mathrm{OR})$ was calculated using a four-fold table with a confidence interval calculation $(\mathrm{Cl})$ using the Woolf's method. The indicators of the gestational age are represented by median and interquartile intervals. To process the results of the research, the non-parametric statistics methods of the licensed software package Statistica for Windows 13 (StatSoft Inc., № JPZ804I382130ARCN10-J), were used.

\section{Results}

The performed molecular and genetic research of the polymorphism of C/T gene FADS2 (rs174583) has shown that the allele $\mathrm{C}$ detection rate was $63.59 \%$ and the $T$ allele detection rate was $36.47 \%, \mathrm{P}<0.05$. The homozygous genotype TT was found in $16.47 \%$ of the examined children and was significantly less common than the homozygous genotype CC $(P<0.05)$ and the heterozygous genotype CT $(\mathrm{P}<0.05)$. The dominant CC genotype and the CT heterozygous genotype were found among examined children with approximately the same frequency, $43.53 \%$ and $40.00 \%$, respectively, no significant differences between the frequencies of genotypes detection were defined.

Among children of the Group I, the homozygous genotype TT was found only in $15.09 \%$, that was significantly less than the $C C$ genotype $(P<0.05)$ and the genotype CT $(P<0.05)$. The homozygous CC genotype was found at $37.47 \%$, the heterozygous genotype at $47.17 \%$; no significant difference was detected in the frequency of occurrence of these genotypes (Fig. 1).

The homozygous genotype TT among children of the Group II was found in $18.18 \%$.

The genotype CC and CT was found in $38.96 \%$ and $42.86 \%$; the frequency of these genotypes occurrence was significantly higher $(P<0.05)$ in comparison with the minor TT genotype (Fig. 2).

Among the children of the Group III, the genotype CC was found in $52.5 \%$ of children, CT - 32.5\%, TT $15.0 \%$. The significant difference between the frequency of occurrence was found only for the genotypes of $\mathrm{CC}$ and TT, $\mathrm{P}<0.05$ (Fig. 3). 
Next we investigated the frequency of allele occurrence in each group.

Among the children of the Group I, allele $C$ was found in $61.3 \%$, allele $\mathrm{T}-38.7 \%$, $(\mathrm{P}<0.05)$. In children of the Group II the allele $\mathrm{C}$ was detected in $60.4 \%$, allele $\mathrm{T}-39.4 \%$, $(\mathrm{P}<0.05)$. Among children of the Group III, the allele $\mathrm{C}$ was found in $68.8 \%$, allele $T-31.3 \%$, $(P<0.05)$. These data are shown in Fig. 4.

According to the Tables 1 and 2, the following conclusions can be drawn: none of the alleles of polymorphism of the gene FADS2 (rs174583) (TT, CT, and CC) revealed a deviation from the Hardy-Weinberg principleboth among children of the Group I $\left(X^{2}=2.33\right.$, OR $(T T)=1.01$; OR $(C T)=1.85$ and $O R(C C)=0.55$, respectively, $P>0.05)$, and among children of the Group II $\left(X^{2}=1.98\right.$, OR $(T T)=1.26$; $\mathrm{OR}(\mathrm{CT})=1.56$ and $\mathrm{OR}(\mathrm{CC})=0.58$ respectively, $\mathrm{P}>0.05)$ compared to the control group.

The state of the nervous system of the examined children, depending on their genotypes, is presented in the Fig. 5, 6, 7. According to a neurologist's opinion, perinatal lesions of the central nervous system (CNS) with syndromes of excitation or inhibition were recorded in most children.

Then, following the purpose of our study, we assessed the neurological status of children with low birth weight taking into account the polymorphism of $\mathrm{C} / \mathrm{T}$ gene FADS2 (rs174583).

In our study we have also analyzed the incidence of convulsive syndrome in children during the neonatal period. It was found that among children with the CC genotype, seizures were recorded in only $5.6 \%$ of the examined ones, significantly less than in patients with the TT genotype $(16.45 \%, \mathrm{P}<0.05)$. Children with CT genotype had seizures in their medical history in $11.41 \%$ of cases, with no significant difference with those examined with $\mathrm{CC}$ and TT genotypes.

In the course of the research, we compared the obtained results of the distribution of the genotypes and alleles of the polymorphism of the gene FADS2 (rs174583) with indices in the global and European populations. In general, the genotype CC was found in $44.7 \%$ in the world population, $41.7 \%$ - in the European population, $43.5 \%$ - in our research; the heterozygous genotype CT was revealed as follows: $36.9 \%, 43.9 \%$ and $43.5 \%$ and the recessive genotype TT $-18.4 \%, 14.5 \%$ and $16.6 \%$, respectively. However, the distribution of genotypes and alleles of the polymorphism of the gene FADS2 (rs174583) in different parts of the world is heterogeneous. Based on the data presented in the Fig. 9 and 10 , it can be concluded that allele $\mathrm{C}$ was more common in South Asia (84.7 \%) and Africa (75.8\%) and less common in America and EastAsia. The allele T was most often found among the inhabitants of America and EastAsia. The homozygous dominant genotype (CC) was most commonly found among the inhabitants of South Asia (76.6\%) and Africa $(57.8 \%)$. The lowest frequency of occurrence of the homozygous genotype (TT) was detected among African residents and was only $6.2 \%$. In the South Asian population surveyed, the recessive homozygous and heterozygous genotype was found to be approximately of the same frequency, $25 \%$ and $26 \%$ respectively (Fig. 10) [30].

The CC and CT genotypes dominated in the inhabitants of those countries where the highest percentage of premature births and the birth of low-weight children was observed.

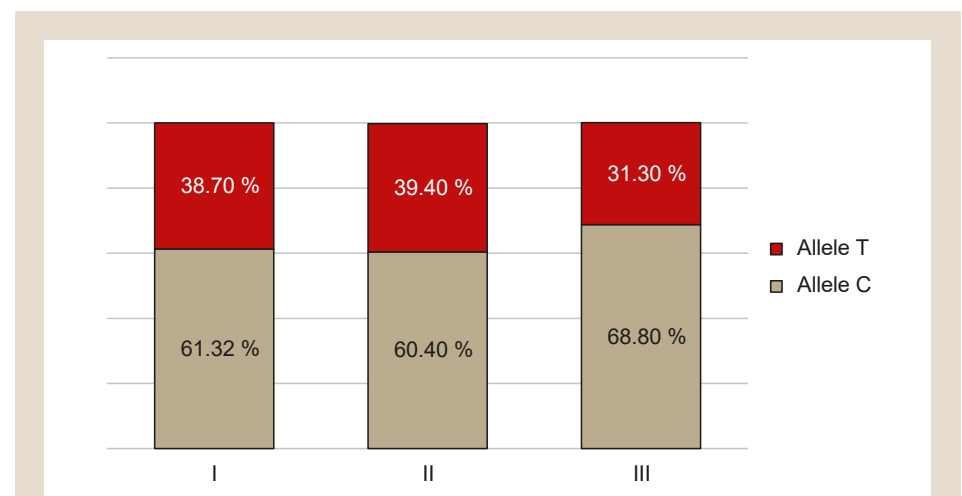

Fig. 4. Frequency of occurrence the polymorphism of C/T gene FADS2 (rs174583).

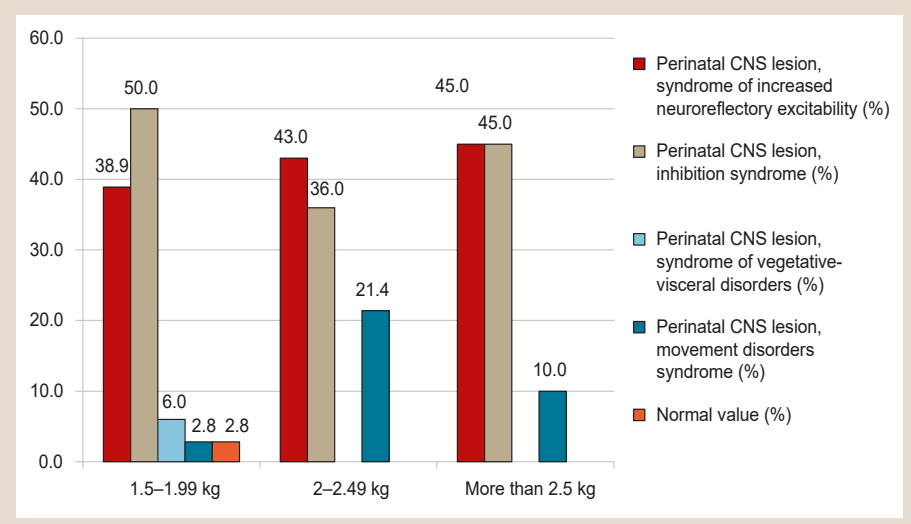

Fig. 5. State of the nervous system in children with CT genotype.

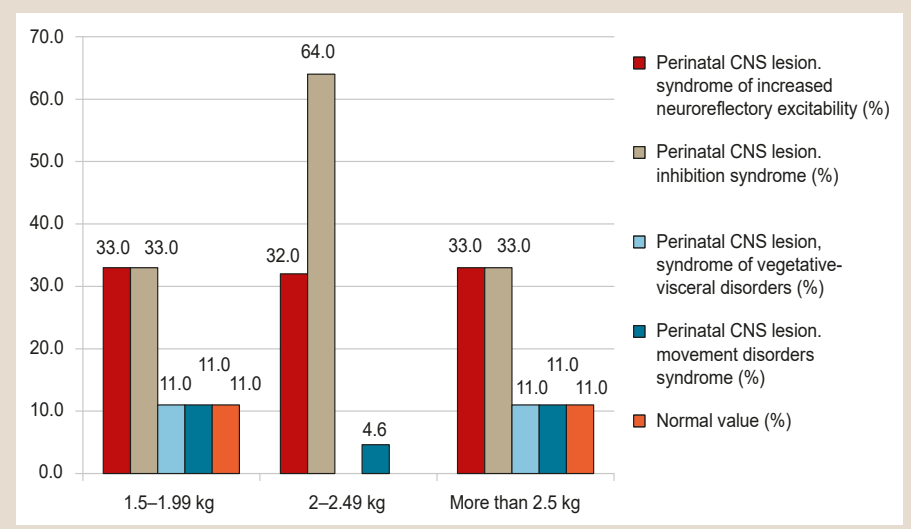

Fig. 6. State of the nervous system in children with CC genotype.

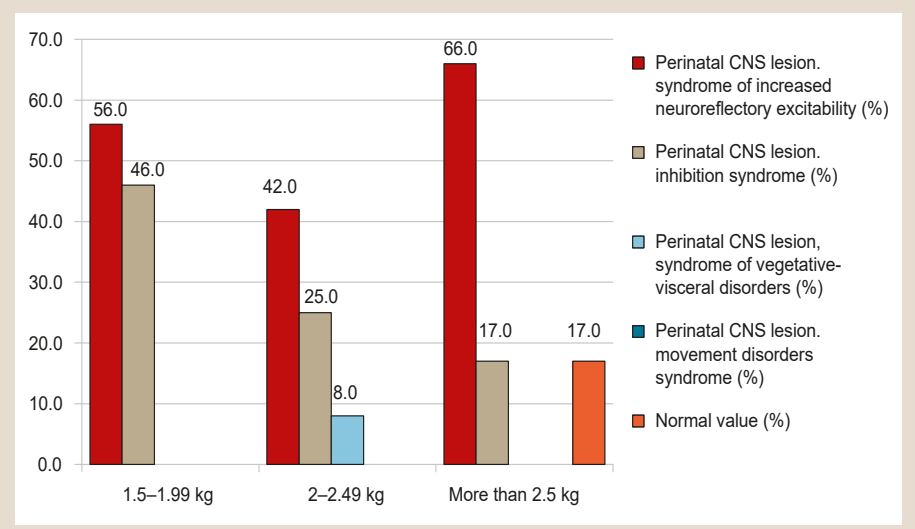

Fig. 7. State of the nervous system in children with TT genotype. 
Table 1. General model for inheriting the polymorphism of C/T gene FADS2 (rs174583) in children of the Group I and the control group

\begin{tabular}{|c|c|c|c|c|c|c|}
\hline \multirow[t]{2}{*}{ Genotype } & \multirow{2}{*}{$\begin{array}{l}\text { Case } \\
n=53\end{array}$} & \multirow{2}{*}{$\begin{array}{l}\text { Control } \\
n=40\end{array}$} & \multirow[t]{2}{*}{$x^{2}$} & \multirow[t]{2}{*}{$p$} & \multicolumn{2}{|l|}{ OR } \\
\hline & & & & & value & $95 \%$ Cl \\
\hline $\mathrm{C} / \mathrm{C}$ & 0.377 & 0.525 & \multirow[t]{3}{*}{2.33} & \multirow[t]{3}{*}{0.31} & 0.55 & $0.24-1.26$ \\
\hline $\mathrm{C} / \mathrm{T}$ & 0.472 & 0.325 & & & 1.85 & $0.79-4.35$ \\
\hline$T / T$ & 0.151 & 0.150 & & & 1.01 & $0.32-3.18$ \\
\hline
\end{tabular}

Table 2. General model for inheriting the polymorphism of C/T gene FADS2 (rs174583) in children of the Group II and the control group

\begin{tabular}{|c|c|c|c|c|c|c|}
\hline \multirow[t]{2}{*}{ Genotype } & \multirow{2}{*}{$\begin{array}{l}\text { Case } \\
\mathrm{n}=77\end{array}$} & \multirow{2}{*}{$\begin{array}{l}\text { Control } \\
n=40\end{array}$} & \multirow[t]{2}{*}{$x^{2}$} & \multirow[t]{2}{*}{$p$} & \multicolumn{2}{|l|}{ OR } \\
\hline & & & & & value & $95 \%$ Cl \\
\hline $\mathrm{C} / \mathrm{C}$ & 0.390 & 0.525 & \multirow[t]{3}{*}{1.98} & \multirow[t]{3}{*}{0.37} & 0.58 & $0.27-1.25$ \\
\hline $\mathrm{C} / \mathrm{T}$ & 0.429 & 0.325 & & & 1.56 & $0.70-3.47$ \\
\hline$T / T$ & 0.182 & 0.150 & & & 1.26 & $0.44-3.57$ \\
\hline
\end{tabular}

Table 3. Total points on the Apgar scale in the 1st and in the 5th minute in children, depending on their genotype of C/T polymorphism of the FADS2 gene (rs1745683)

\begin{tabular}{|c|c|c|c|c|c|c|}
\hline \multirow[t]{2}{*}{ Genotypes } & Group I & Group II & Group III & Group I & Group II & Group III \\
\hline & \multicolumn{3}{|c|}{ Apgar scale evaluation in the $1^{\text {st }}$ minute } & \multicolumn{3}{|c|}{ Apgar scale evaluation in the $5^{\text {th }}$ minute } \\
\hline $\mathrm{CC}$ & $7.0(6.0 ; 7.0)$ & $7.0(6.0 ; 8.0)$ & $8.0(7.0 ; 9.0)$ & $7.0(7.0 ; 8.0)$ & $8.0(7.0 ; 8.0)$ & $9.0(7.0 ; 9.0)$ \\
\hline CT & $6.0(5.0 ; 7.0)^{*, *}$ & $7.0(7.0 ; 8.0)^{*}$ & $7.5(6.0 ; 8.0)^{*}$ & $7,0(7,0 ; 7,5)^{\star \star *, \wedge}$ & $8.0(7.0 ; 8,0)^{\star \star \star}, \wedge \wedge$ & $8.0(8.0 ; 9.0)^{\wedge, \wedge \wedge}$ \\
\hline TT & $5.0(5.0 ; 6.0)$ & $7.0(7.0 ; 7.0)$ & $7.0(7.0 ; 7.5)$ & $6.0(6.0 ; 7.0) \#$ & $8.0(7.0 ; 8.0) \#$ & $7.5(7.0 ; 8.5)$ \\
\hline
\end{tabular}

*: $\mathrm{P}<0.05$ significant difference between the total points on the Apgar scale in the 1 st minute for children of groups I and II with the C/T genotype; **: P< 0.05 significant difference between the total points on the Apgar scale in the $1^{\text {st }}$ minute for children of groups I and III with the C/T genotype; ***: P $<0.05$ significant difference between the total points on the Apgar scale in the $5^{\text {th }}$ minute for children of groups I and II with the C/T genotype; ${ }^{\wedge}: \mathrm{P}<0.05$ significant difference between the total points on the Apgar scale in the $5^{\text {th }}$ minute for children 1 and 3 minutes with the C/T genotype; ${ }^{\wedge}: \mathrm{P}<0.05$ significant difference between the total points on the Apgar scale in the $5^{\text {th }}$ minute for children of groups II and III with the $\mathrm{C} / \mathrm{T}$ genotype; \#: $\mathrm{P}<0.05$ significant difference between the total points on the Apgar scale in the $5^{\text {th }}$ minute for children of groups I and II with the T/T genotype.

Table 4. Total points of neurological signs in children with the genotype C/C of the FADS2 gene (rs1745683)

\begin{tabular}{l|l|l|l|l|l|l|l|l|l|l|}
\multirow{2}{*}{ Groups } & \multicolumn{9}{l}{ Neurological symptoms } \\
\cline { 2 - 11 } & $\mathbf{1}$ & $\mathbf{2}$ & $\mathbf{3}$ & $\mathbf{4}$ & $\mathbf{5}$ & $\mathbf{6}$ & $\mathbf{7}$ & $\mathbf{8}$ & $\mathbf{9}$ & $\mathbf{1 0}$ \\
$\mathrm{II}$ & $1.0(1.0 ; 3.0)$ & $1.0(1.0 ; 3.0)$ & $1.0(1.0 ; 3.0)$ & $1.0(1.0 ; 3.0)$ & $1.0(1.0 ; 3.0)$ & $1.0(1.0 ; 3.0)$ & $1.0(1.0 ; 3.0)^{*}$ & $1.0(1.0 ; 3.0)$ & $1.0(1.0 ; 3.0)$ & $1.0(1.0 ; 3.0)^{* * \wedge}$ \\
II & $3.0(1.0 ; 3.0)$ & $3.0(1.0 ; 3.0)$ & $3.0(1.0 ; 3.0)$ & $3.0(1.0 ; 3.0)$ & $3.0(1.0 ; 3.0)$ & $3.0(1.0 ; 3.0)$ & $3.0(1.0 ; 3.0)^{*}$ & $3.0(1.0 ; 3.0)$ & $3.0(1.0 ; 3.0)$ & $3.0(1.0 ; 3.0)^{* *}$ \\
\hline III & $3.0(2.5 ; 3.0)$ & $3.0(2.5 ; 3.0)$ & $3.0(2.5 ; 3.0)$ & $3.0(2.5 ; 3.0)$ & $3.0(2.5 ; 3.0)$ & $3.0(2.5 ; 3.0)$ & $3.0(2.5 ; 3.0)$ & $3.0(2.5 ; 3.0)$ & $3.0(2.5 ; 3.0)$ & $3.0(2.5 ; 3.0)^{\wedge}$ \\
\hline
\end{tabular}

Coding of neurological symptoms in the Table:

1: "Posture"; 2: "Square window"; 3: "Flexion of the foot"; 4: "Hand response"; 5: "Foot response"; 6: "Popliteal angle"; 7: "Pulling the child's heel to the ear"; 8: "Symptom of oblique movement"; 9 : "Delay of head movement from body movement"; 10: "Abdominal suspension of the newborn".

*: P $<0.05$ significant difference between the total points in children of groups I and II with the C/C genotype on the basis of "pulling the child's heel to the ear"; **: $\mathrm{P}<0.05$ significant difference between the total points in children of groups I and II with the $\mathrm{C} / \mathrm{C}$ genotype on the basis of "abdominal suspension of the newborn"; ${ }^{\wedge}: \mathrm{P}<0.05$ significant difference between the total points in children of groups I and III with the CC genotype on the basis of "abdominal suspension of a newborn".

But data obtained in relation to America was controversial. Thus in America the premature births make up about $9 \%$ and this indicator is high. However, homozygous recessive genotype TT ( $40.9 \%)$ and heterozygous genotype CT $(40.6 \%)$ are more common among Americans against $18.4 \%$ of CC genotype. According to reported data, among African, African-American, African-Caribbean women, there is a greater risk of premature birth than among women of the white race. This can partly explain such a large percentage of premature birth of children [2,30]. It is also conceivable that the emergence of new reproductive technologies also contributes to the increase of this indicator.

The evaluation results of the examined children on the Apgar scale depending on the genotype of the C/T polymorphism of the FADS2 gene ( $r$ 1745683) are presented in the Table 3. Thus, it was found that the number of points on the Apgar scale for both in the 1st and in the 5th minute in children of group I with $\mathrm{C} / \mathrm{T}$ genotype is significantly lower than in children of groups II and III $(P<0.05)$. In addition, children of group II with the $\mathrm{C} / \mathrm{T}$ genotype had significantly lower total points on the Apgar scale in the 5th minute than children of group III. In children of group I with the T/T genotype, the total points on the Apgar scale in the $5^{\text {th }}$ minute was significantly less than in children of group II with the same genotype. There were no significant differences in the total points on the Apgar scale in children of all three groups with the $\mathrm{C} / \mathrm{C}$ genotype.

Since there are no special scales for evaluating the state of the nervous system in premature babies, we took 10 neurological signs of the Dubovich scale. The data are presented in the Tables 4-6. A significant difference in the total points was revealed in children of groups I and II with the $\mathrm{C} / \mathrm{C}$ genotype according to the neurological symptoms "pulling the child's heel to the ear" and "abdominal suspension of the newborn". Also, children of group I had significantly lower total points than children of group III on the basis of "abdominal suspension of a newborn".

Among heterozygous $\mathrm{C} / \mathrm{T}$ carriers of the FADS2 gene (rs1745683), children of group I had a significantly low number of points in comparison to children of group III 
Table 5. Total points of neurological signs in children with the genotype C/T of the FADS2 gene (rs1745683)

\begin{tabular}{|c|c|c|c|c|c|c|c|c|c|c|}
\hline \multirow[t]{2}{*}{ Groups } & \multicolumn{10}{|c|}{ Neurological symptoms } \\
\hline & 1 & 2 & 3 & 4 & 5 & 6 & 7 & 8 & 9 & 10 \\
\hline I & $1.0(0 ; 3.0)^{*}$ & $1.0(0 ; 3.0)^{\star *}$ & $1.0(0 ; 3.0)$ & $1.0(0 ; 3.0)$ & $1.0(0 ; 3.0)$ & $1.0(0 ; 3.0)$ & $1.0(0 ; 3.0)$ & $1.0(0 ; 3.0)$ & $1.0(0 ; 3.0)$ & $1.0(0 ; 3.0)$ \\
\hline ॥ & $2.0(1.0 ; 3.0)$ & $2.0(1.0 ; 3.0)$ & $2.0(1.0 ; 3.0)$ & $2.0(1.0 ; 3.0)$ & $2.0(1.0 ; 3.0)$ & $2.0(1.0 ; 3.0)$ & $2.0(1.0 ; 3.0)$ & $2.0(1.0 ; 3.0)$ & $2.0(1.0 ; 3.0)$ & $2.0(1.0 ; 3.0)$ \\
\hline III & $3.0(1.0 ; 3.0)^{*}$ & $3.0(1.0 ; 3.0)^{\star *}$ & $3.0(1.0 ; 3.0)$ & $3.0(1.0 ; 3.0)$ & $3.0(1.0 ; 3.0)$ & $3.0(1.0 ; 3.0)$ & $3.0(1.0 ; 3.0)$ & $3.0(1.0 ; 3.0)$ & $3.0(1.0 ; 3.0)$ & $3.0(1.0 ; 3.0)$ \\
\hline
\end{tabular}

Coding of neurological symptoms in the Table:

1: "Posture"; 2: "Square window"; 3: "Flexion of the foot"; 4: "Hand response"; 5: "Foot response"; 6: "Popliteal angle"; 7: "Pulling the child's heel to the ear"; 8: "Symptom of oblique movement"; 9: "Delay of head movement from body movement"; 10: "Abdominal suspension of the newborn".

*: $\mathrm{P}<0.05$ significant difference between the total points in children of groups I and III with the C/T genotype according to the "posture" attribute: **: $\mathrm{P}<0.05$ significant difference between the total points in children of groups I and III with the C/T genotype according to the "square window".

Table 6. Total points of neurological signs in children with the T/T genotype of the FADS2 gene (rs1745683)

\begin{tabular}{|c|c|c|c|c|c|c|c|c|c|c|}
\hline \multirow[t]{2}{*}{ Groups } & \multicolumn{10}{|c|}{ Neurological symptoms } \\
\hline & 1 & 2 & 3 & 4 & 5 & 6 & 7 & 8 & 9 & 10 \\
\hline I & $1.5(0.5 ; 2.5)$ & $1.5(0.5 ; 2.5)$ & $1.5(0.5 ; 2.5)^{\wedge}$ & $1.5(0.5 ; 2.5)$ & $1.5(0.5 ; 2.5)$ & $1.5(0.5 ; 2.5)^{\wedge \wedge}$ & $1.5(0.5 ; 2.5)^{*}$ & $1.5(0.5 ; 2.5)$ & $1.5(0.5 ; 2.5)$ & $1.5(0.5 ; 2.5)^{\star \star}$ \\
\hline II & $2.5(1.0 ; 3.0$ & $2.5(1.0 ; 3.0$ & $2.5(1.0 ; 3.0$ & $2.5(1.0 ; 3.0$ & $2.5(1.0 ; 3.0$ & $2.5(1.0 ; 3.0$ & $2.5(1.0 ; 3.0)^{*}$ & $2.5(1.0 ; 3.0$ & $2.5(1.0 ; 3.0$ & $2.5(1.0 ; 3.0)^{\star \star, \#}$ \\
\hline III & $3.0(3.0 ; 3.0)$ & $3.0(3.0 ; 3.0)$ & $3.0(3.0 ; 3.0)^{\wedge}$ & $3.0(3.0 ; 3.0)$ & $3.0(3.0 ; 3.0)$ & $3.0(3.0 ; 3.0)^{\wedge \wedge}$ & $3.0(3.0 ; 3.0)$ & $3.0(3.0 ; 3.0)$ & $3.0(3.0 ; 3.0)$ & $3.0(3.0 ; 3.0)^{\#}$ \\
\hline
\end{tabular}

Coding of neurological symptoms in the Table:

1: "Posture"; 2: "Square window"; 3: "Flexion of the foot"; 4: "Hand response"; 5: "Foot response"; 6: "Popliteal angle"; 7: "Pulling the child's heel to the ear"; 8: "Symptom of oblique movement"; 9 : "Delay of head movement from body movement"; 10: "Abdominal suspension of the newborn".

*: $\mathrm{P}<0.05$ significant difference between the total points in children of groups I and II with the T/T genotype on the basis of "pulling the child's heel to the ear"; **: $\mathrm{P}<0.05$ significant difference between the total points in children of groups I and II with the T/T genotype on the basis of "abdominal suspension of the newborn"; $\wedge$ : P < 0.05 significant difference between the total points in children of groups I and III with the T/T genotype on the basis of "flexion of the foot"; ${ }^{\wedge}: \mathrm{P}<0.05$ significant difference between the total points in children of groups I and III with the T/T genotype according to the "popliteal angle"; \#: P< 0.05 significant difference between the total points in children of groups II and III with the T/T genotype on the basis of "abdominal suspension of the newborn".
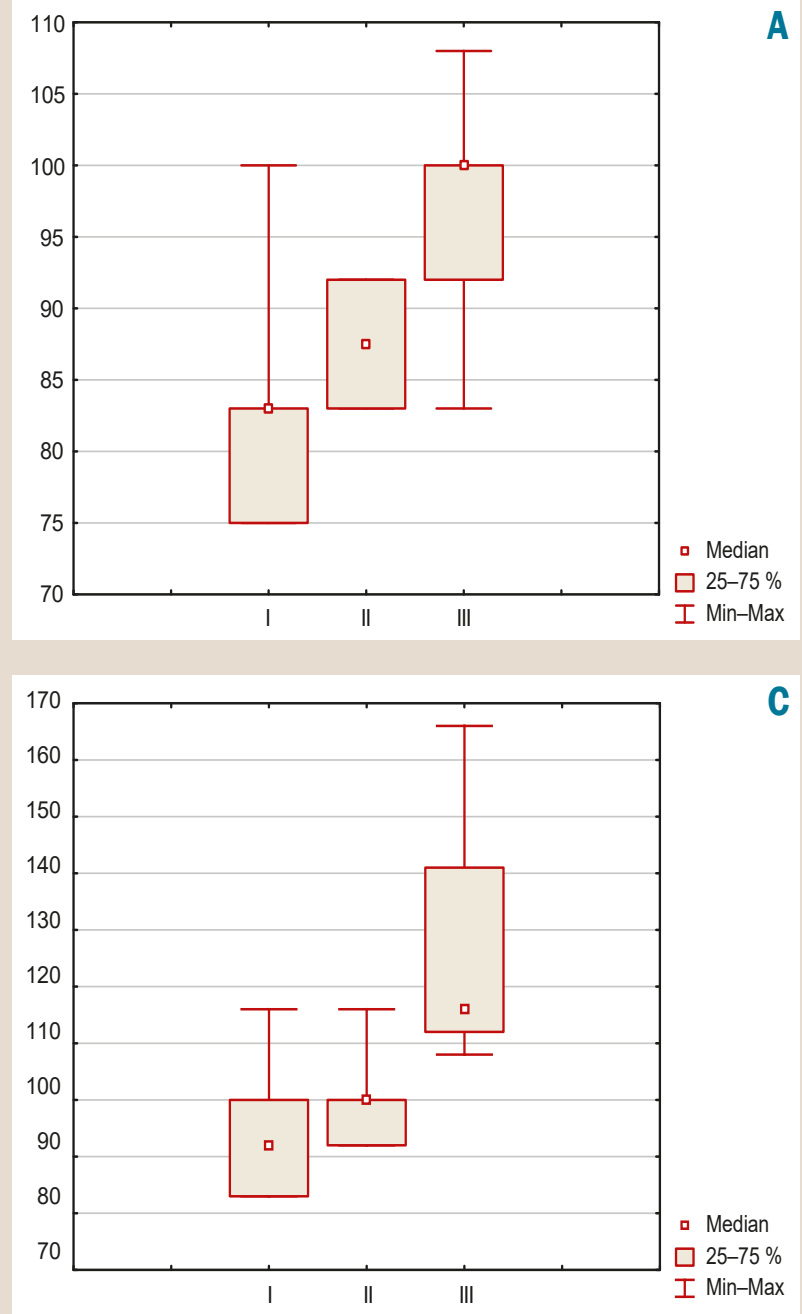

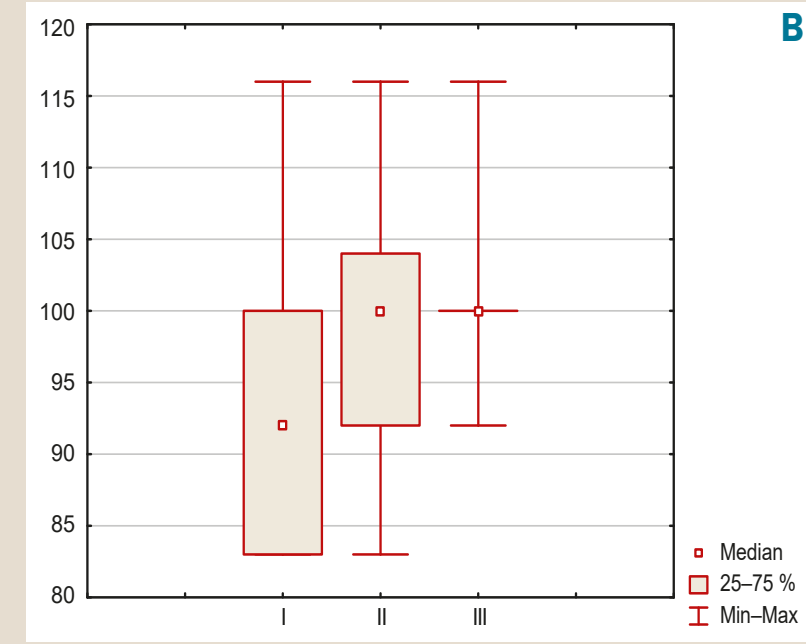

Fig. 8. Indicators of the coefficient of neuropsychic development of children. A: genotype $T / T$;

B: genotype $\mathrm{C} / \mathrm{T}$;

C: genotype $\mathrm{C} / \mathrm{C}$. 


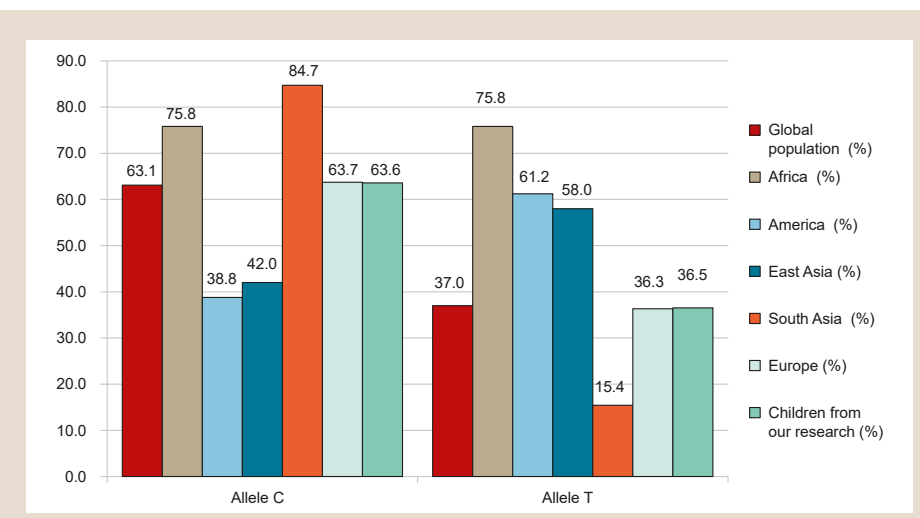

Fig. 9. Comparative characteristics of the frequency of occurrence of the alleles of the polymorphism of the gene FADS2 (rs174583) in the world population.

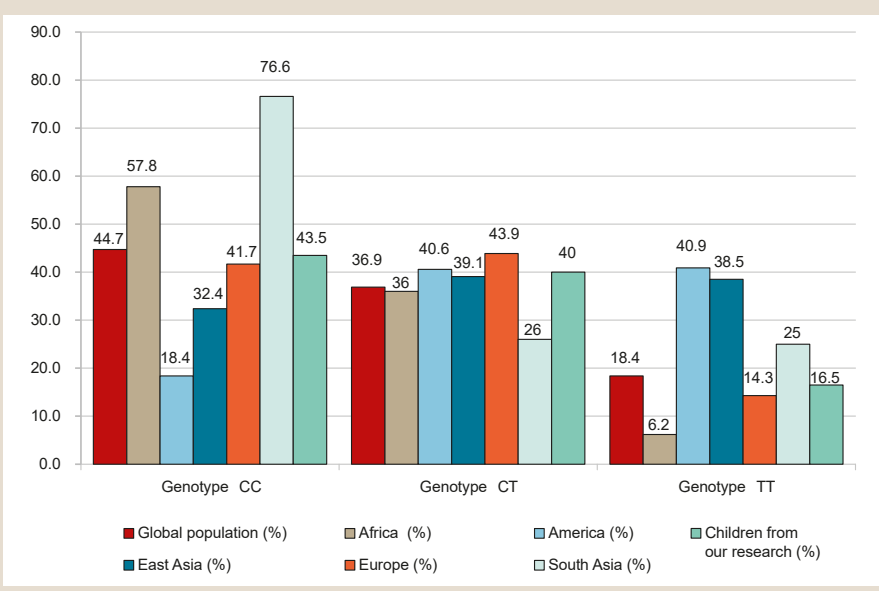

Fig. 10. Comparative characteristic of the frequency of occurrence of the genotypes $C C, C T, T T$ polymorphism of the gene FADS2 ( $r$ 174583) in the world population.

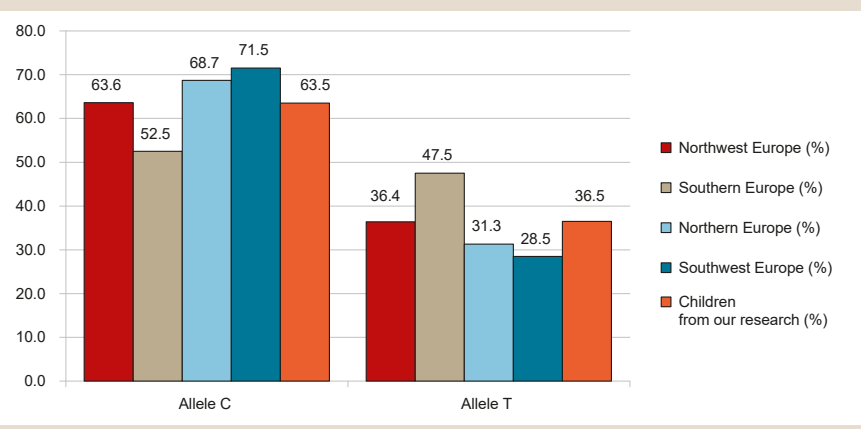

Fig. 11. Distribution of the of the alleles of the polymorphism of the gene FADS2 (rs174583) in the European population.

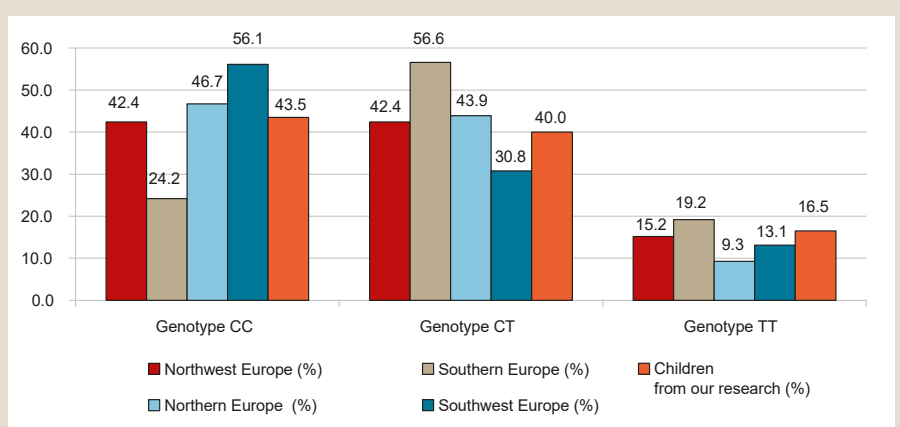

Fig. 12. Comparison of detection frequency of the genotypes of polymorphism of the gene FADS2 (rs174583) in the European population and the researched group. according to the neurological symptoms of "posture" and "square window".

Among children with the T/T homozygous genotype, a significant difference between the total points in children of groups I and II was recorded according to neurological symptoms: "pulling the child's heel to the ear", "abdominal suspension of the newborn"; in children of groups I and III - "flexion of the foot", "popliteal angle"; in children of groups II and III - "abdominal suspension of the newborn".

Subsequently, in children aged 12 months, an evaluation of psychomotor development was carried out with the determination of the QD index or the coefficient of neuropsychic development. In homozygotes for allele C, we obtained the following average QD indicators: in group I, $92.0(83.0 ; 100.0)$, which corresponded to the average normal level; in group II - $100.0(92.0 ; 100.0)$, as the average normal level; in group III - $116.0(112.0 ; 141.0)$ or a normal high level. A significant difference in the index of neuropsychological development was revealed between all groups. Among heterozygotes, the average QD in the group I under examination was 92.0 (83.0; $100.0)$, in the group II $-100.0(92.0 ; 104.0)$, in the group III - $100.0(100.0 ; 100.0)$, with a statistical difference of $p<0.05$ between groups I and III, but nevertheless within the average normal values of the neuropsychic development of children. In homozygotes for T allele, indicators of the index of neuropsychic development in children from group I were significantly lower than in children from group III. So, in the first group of observation, the development coefficient QD was 83.0 (75.0; $83.0)$, in the second group - $87.50(83.0 ; 92.0)$ and these indicators corresponded to a weak normal level of neuropsychic development of children, and in group III - 100.0 (92.0; 100.0), which is within the average normal level of neuropsychic development (Fig. 8).

In our study, we have determined that children with a birth weight of 1500-1999 $\mathrm{g}$ and 2000-2499 $\mathrm{g}$ with minor homozygous $\mathrm{T} / \mathrm{T}$ genotypes had lower rates of neuropsychological development, which indicated a weak normal level of their neuropsychic development compared with children in whom a major homozygous $\mathrm{C} / \mathrm{C}$ or heterozygous C T genotype of polymorphism of the FADS2 gene (rs174583) with an average normal level of neuropsychological development was detected, while a normal high level was recorded only in the patients with a homozygous type $\mathrm{C} / \mathrm{C}$ and a birth weight of $2500 \mathrm{~g}$.

It is possible that the predominance of the $\mathrm{C} / \mathrm{C}$ dominant genotype and the $\mathrm{C} / \mathrm{T}$ heterozygous genotype plays a protective function in order to reduce the negative effects on the nervous system associated with premature birth.

\section{Discussion}

We have also compared the data we obtained and the distribution of genotypes in the world population: the frequency of occurrence of the genotype CC in the examined children is closer to the data of Europe, the frequency of occurrence of the genotype CT holds an intermediate position with respect to data from Europe, America and East Asia, the genotype TT - to the data from Europe and Africa. With regard to the distribution of alleles $C$ and $T$, the results we obtained correspond to the frequency of occurrence of 
the indicated polymorphism among European residents [31] (Fig. 9 and 10).

Further on we examined and analyzed more in detail the detection frequency of alleles and genotypes of the polymorphism of the gene FADS2 (rs174583) with the data of European populations. The results of our study, obtained by us, are closer to the distribution frequency of genotypes and alleles of the inhabitants of Northwest Europe (Fig. 11, 12).

Considering the hypothesis that there is a relationship between a certain genotype of FADS2 polymorphism and the metabolism of polyunsaturated fatty acids, which causes brain myelination, and, consequently, neuropsychic, psychomotor and cognitive development, we analyzed other scientific studies in this area.

Thus, according to the literature sources on this problem, Adam Ameur and colleagues studied SNP genotype data in 5652 individuals from five European populations (Sweden, Italy, Scotland, Croatia and the Netherlands), and subsequently a targeted re-study was conducted in 960 people. Scientists have proved that the determination of the minor genotype of FADS2 polymorphism (rs174583) is associated with a lower plasma content of long chain $\omega-6$ and $\omega-3$ fatty acids, and the major genotype FADS2 (rs174583) is associated with a higher content of polyunsaturated fatty acids. Also, when comparing these data with data on the distribution of FADS genotypes in other geographical regions and populations, it was concluded that the distribution of genotypes differs sharply between continents [32].

Thus, in African populations the minor haplotype is practically absent (1\% of chromosomes), whereas in Europe, West, South and East Asia, as well as in Oceania, it occurs with a frequency of $25-50 \%$. Among 126 Native Americans, the minor haplotype is $97 \%$ of the chromosomes, that is, it occurs with a very low frequency among people of African descent, while in populations of European and Asian descent it is present with moderate or high frequency. FADS mixed haplotypes were found in $49 \%$ of people of African descent. In general, a significant decrease in FADS heterozygosityis observed in populations of Africa and America. An inter-population extended homozygosity test, when the selected allele has achieved fixation in one population, but remains polymorphic in the human population as a whole, shows a distinct peak in the registration of the FADS homozygous genotype among the African population. Consequently, FADS is one of the five best candidate genes that were obtained during long-term positive selection in African populations and is interrelated with the metabolism of polyunsaturated fatty acids [32].

To date, according to B. D. Peters et al., it is also known that the characteristics of the metabolism of polyunsaturated fatty acids were due to genetic factors, including certain FADS2 genotypes, which affect the rate of cerebral myelination. At the same time, polyunsaturated fatty acids are involved in the development of the white matter of the human brain during both childhood and adulthood. This was proved by examining 207 healthy people (male $53 \%$ ) aged 9 to 86 years. According to the results of a genetic study of the polymorphism of the FADS2 gene (rs174583), 177 major allelic (C) carriers (88 SS homozygotes, $89 \mathrm{C} / \mathrm{T}$ heterozygotes) and 30 minor allelic (T) homozygotes were identified. Moreover, in all examined with the FADS2 minor genotype, the development of white matter was slower, which was reflected in the functioning of the brain. Nevertheless, the IQ level for carriers of the major genotype was $112 \pm 11$ versus $113 \pm 12$ for carriers of the minor genotype [20].

At the same time, Nicolas W. Martin and colleagues also showed that when examining 1431 Australian teenage twins raising in 700 families, there was no significant relationship between cognitive functions with the determination of an IQ indicator, the presence of breastfeeding, and FADS2 gene polymorphism. However, adolescents who were C-allelic carriers of the rs 174575 single nucleotide polymorphism and were breastfed showed an IQ level of 6.4-7.0 points higher than the same $\mathrm{C}$-allelic carriers of the same name SNP of the FADS2 gene, but who were breast-fed [33].

But later on, M. Martinez and E. Vazquez showed in their study that there was a link between the accumulation of docosahexaenoic acid as a representative of polyunsaturated fatty acids and myelination of the brain, especially in the first year of life. In other words, insufficient synthesis of polyunsaturated fatty acids can affect the myelination of the brain and subsequently affect the cognitive development of children in the future. Thus, when receiving a daily dose of docosahexaenoic acid (DHA) from $200 \mathrm{mg}$ to $600 \mathrm{mg}$ from 18 months to 3 years, in children at normalization of DHAlevel in plasma and blood improvement in liver function was observed, evidenced by a decrease in liver enzymes to almost normal values, an increase muscle tone and motor development, improvement of social, visual, auditory contact of children with others; children began to follow the light source, walk, etc. At repeated magnetic resonance imaging (MRI) made after treatment, the normalization of myelination of the brain was observed. Moreover, these positive changes in MRI were positively correlated with the improvement of patients' motor skills [34].

Similarly, the data from Ricardo Uauy and Patricia Mena also prove that polyunsaturated fatty acids can partially offset the negative effects of preterm birth. Arachidonic acid and docosahexaenoic acid (DHA) can mitigate the effects of hypoxia and oxidative brain damage, affecting the recovery and development of the nervous system. Thus, docosahexaenoic acid accounts for $40 \%$ of polyunsaturated fatty acids of the brain and $60 \%$ of polyunsaturated fatty acids of the retina, with $50 \%$ of the plasma membrane of neurons also consisting of DHA [35].

These basic studies were also confirmed by the results of Emily W. Y. Tam's et al., who showed that higher levels of docosahexaenoic acid in the first weeks of life were associated with a decrease in the incidence of intracranial hemorrhage, with a faster rate of brain microstructures and a decrease in adverse effects of nervous system among premature babies. Thus, in 60 preterm infants, namely 33 children from the University of California San Francisco (UCSF) and 27 children from the University of British Columbia (UBC) at $31.54 \pm 2.26$ weeks, the mean docosahexaenoic acid (DHA) level was $4.4 \%(2.0-6.4 \%)$, eicosapentaenoic acid (EPA) - $0.3 \%(0.1-4.0 \%)$, arachidonic acid (ARA) - $16.4 \%$ (10.8-20.4\%), linoleic acid (LA) $9.2 \%(5.9-14.1 \%)$. It was found that in the fifth minute after birth, the Apgar scale of 33 children with UCSF was 8 (7-8) points, and 27 children with UBC 8 (6-8) points. However, magnetic resonance imaging (MRI) has shown mild and severe intra-ventricular hemorrhage (IVH) in premature infants 
from UCSF in $12 \%$ and $18 \%$ of cases, in patients from UBC in $19 \%$ and $4 \%$ of cases, respectively. In almost 6 weeks $44 / 60(73 \%)$ of surveyed children had already the average DHA level of $4.5 \%(0.7-7.7 \%)$, EPA - $0.4 \%(0.1-0.8 \%)$, ARA - $16.6 \%$ (3.7-19.2 \%), LA - $10.4 \%$ (6.2-14.5\%). Further logistic regression analysis showed that one percent increase in DHA was associated with a 4.3-fold decreased odds of IVH $(P=0.024)$ and lower DHA levels were associated with higher IVH severity. Thus, one percent increase in DHA was associated with a 2.3-fold decreased odds of increasing one degree of IVH severity $(95 \% \mathrm{Cl} 1.06-5.27$, $\mathrm{P}=0.036$ ) and one percent increase DHA was associated with 3.9-fold decreased odds of increasing one degree of IVH severity (95 \% Cl 1.22-12.28, P = 0.022) [36].

Today, modern researchers have nevertheless proved that breast milk is an important source of polyunsaturated fatty acids for children, so those children who are fed with artificial mixtures have insufficient consumption of such acids.

The consequences of insufficient consumption of polyunsaturated fatty acids with breast milk are shown in the work of Beth A. Plunkett, who studied the effect of breastfeeding on the IQ level of 756 children aged $60.1 \pm 1.7$ months. So, $31 \%$ of children had breastfeeding for less than 3 months, $20 \%$ - from 4 to 6 months, $11 \%$ - from 7 to 9 months, $15 \%$ - from 10 to 12 months, $23 \%$ - for more than 12 months. At the same time, children who were breastfed, regardless of the duration of breastfeeding, had higher IQ values over the age of 5 years $(I Q=96.7 \pm 15.1)$ than children who did not receive breast milk $(I Q=91.2 \pm 15.0), P<0.001)$. And lower $I Q$ (less than 85 ) were also more often recorded in children on artificial against the children on breastfeeding (36.2\% versus $21.5 \%$ of the examined) [37].

When examining 790 American children using intelligence tests, Boutwell B.B. also proved that there was a statistically significant correlation between breastfeeding during the first six months of life and intelligence, both in childhood and adolescence [38]. These data are consistent with a study by Linda P. Siziba et al., who studied the association between breastfeeding, plasma polyunsaturated fatty acids, growth and psychomotor development in 353 children: 187 (53\%) boys and 166 (47\%) girls from South Africa at the age of $6.2 \pm 0.3$ months. It also follows from this study that the eye-hand coordination sub-scale indicator was $20.4(20.1 ; 20.7)$ and locomotor skills sub-scale score$16.4(16.1 ; 16.6)$ [39].

In Poland, MonikaA. Zielinska studied the psychomotor development of 39 children using the Child Development Scale (DSR). At the same time, the high level of polyunsaturated fatty acids in breast milk, which the baby received in the first three months of his life, also increased his motor development at the sixth month of life. So, in the mother's milk of these children, the average concentrations of docosahexaenoic acid (DHA), arachidonic acid (AA) and a-linolenic acid (ALA) were $0.50 \%, 0.19 \%$ and $1.2 \%$ of fatty acids, respectively, and the results of the evaluation of psychomotor development of children at the sixth month of life showed that the average total points on the DSR scale was 39 points $(95 \% \mathrm{Cl} 35-43)$ and ranged from 16 to 74 points [40].

Thus, when evaluating the psychomotor development of children who are on different types of feeding, a pace delay of psychomotor development in the first year of life was recorded in $30 \%$ of those examined on artificial feeding and in $23 \%$ on breastfeeding [41].

Babaeva L. A. and Gafurzhanova H. A. also showed that neuropsychic development in 40 breast-fed children corresponded to the age norm in $92.5 \%$ of cases; moderate delay was recorded in $5.0 \%$ of cases and neuropsychic development was delayed only in $2.5 \%$ of cases. Among 40 mixed-fed children, a moderate delay was fixed in $7.5 \%$ of cases, and a delay in neuropsychic development was also fixed in $2.5 \%$ of cases. At the same time, in 40 children who were breast-fed, moderate delay was observed in $7.5 \%$, and mental retardation was recorded in $12.5 \%$ of patients $(P<0.05)$ [42].

Now, children born with low birth weight need special attention of pediatricians. This is associated with a high risk of disability formation in the first year of life, including due to damage to the nervous system. So, D. L. Nefedieva and I. G. Goriunova, when studying the state of health in 49 preterm infants with gestational age at birth of $28.7 \pm 2.2$ weeks and birth weight of $1267.6 \pm 453.9 \mathrm{~g}$, showed that by the first year of life, 21 patients $(42.9 \%)$ had disabilities. Moreover, the structure of disabilities included diseases of the nervous system in 10 (47.6\%) children, pathologies of the respiratory system in $4(19.1 \%)$ patients, pathologies of the visual system in 4 (19.1\%) patients and pathologies of the hearing system in $3(14.3 \%)$ patients [43].

The study results of neuropsychic development in the first six months of life of 72 children ( 25 boys ( $34.72 \%$ ) and 47 girls $(65.28 \%)$ with a prenatal growth retardation in the history were presented by D.O. Ivanov et al. Thus, evaluation on the Apgar scale showed 7-8 points in 15 $(20.83 \%)$ children and 8-9 points in $57(79.17 \%)$ children. In newborns, the clinical syndromes such as central nervous system (CNS) depression were recorded in 21 (44.68 \%) (CNS), CNS excitations - in 8 (17.02\%) and autonomic disorders - in 18 (38.3\%) (CNS). At the age of six months a violation of muscle tone (usually a decrease or dystonia) was observed in $21.57 \%$ of children. The frequency and severity of neuropsychic development disorders in children increased by six months. Thus, lower harmonious development was detected in $35.29 \%$ of children, and inharmonious neuropsychic development was observed in $54.9 \%$, while there was a difficulty in turning from the abdomen to the back or the children did not start to crawl in $21.57 \%$ of cases, did not eat from the spoon, did not open their mouth before the spoon touched the lips, did not pick the food with their lips $-13.73 \%$, did not respond to their own and someone else's name - to $19.61 \%$, and in general did not say some syllables $-70.59 \%$ of the children. Lag of neuropsychic development of the $1 \mathrm{st}$ and $2^{\text {nd }}$ degrees of severity occurred in $60.78 \%$ and $5.88 \%$ of patients, respectively [44].

Also, Cathy Monteith et al., when examining 41 children with an abnormal cerebro-placental ratio, showed that their gestational age at birth was $33.6 \pm 4.3$ weeks and weight $1603 \pm 684$ grams. In the fifth minute after birth, the value on the Agar scale was less than 7 points in 3 children (7.3\%). At three years old, the growth of these children was $92.3 \pm 4.4$ $\mathrm{cm}$, weight $-13.9 \pm 1.7 \mathrm{~kg}$, head circumference $-49.0 \pm 1.8$ $\mathrm{cm}$. At the same time, the indicators of the below average level of cognitive development were recorded at in $23 \%$ and motor development - in $35 \%$ of cases [45]. 
Ira Adams-Chapman and colleagues studied the psychomotor development of 2134 premature babies who were born at $25.0 \pm 1.0$ weeks of gestational age with a weight of $760 \pm 154$ grams. At the same time, $11 \%$ of children had severe intra-ventricular hemorrhage. The Bayley Scales of infant Development-III and a standardized neurosensory examination was conducted in these children aged 18 to 26 months. In dynamics, the survey showed that neurological disorders were recorded in $22 \%$, and suspected neurological disorders were detected in $19 \%$ of children, while $59 \%$ of patients did not have pronounced neurological disorders. Nevertheless, $11.7 \%$ of children had cerebral palsy, although during the observation period, the frequency of severe cerebral palsy decreased from $26 \%$ to $16 \%$. Moreover, the average indicators showing the level of gross motor were in the range of $7.5 \pm 2.8$, and fine motor $-8.6 \pm 2.9$ [46].

But when evaluating the psychomotor development of 1433 children, Rejane C. Marques et al. nevertheless proved that the growth and psychomotor development of a child is positively influenced by the presence of fish in the mother's diet during pregnancy as a source of polyunsaturated fatty acids and breastfeeding [47].

As a result of our work, we determined that children with a minor genotype of FADS2 polymorphism (rs174583) and birth weight less than $2500 \mathrm{~g}$ had lower rates of neuropsychic development (quolient development, QD) and a weak normal level of neuropsychic development compared to children in which a major homozygous or heterozygous variant of the FADS2 gene polymorphism genotypes (rs174583) with an average normal level of neuropsychological development was detected. At the same time, a normal high level of neuropsychic development was recorded in children with a homozygous $\mathrm{C} / \mathrm{C}$ genotype and a weight of more than $2500 \mathrm{~g}$.

In the future, we plan to conduct a comparative analysis of the clinical and anamnesis data of children born with low body weight, including those related to the presence and duration of breastfeeding, mixed or artificial feeding, depending on the characteristics of their genotype of polymorphism of the FADS2 gene (rs1745683).

\section{Conclusions}

1. Frequency of detection of the allele $\mathrm{C}$ of the polymorphism of C/T gene FADS2 (rs174583) was $63.59 \%$ and the allele $\mathrm{T}-36.47 \%(\mathrm{P}<0.05)$. The homozygous genotype TT observed in $16.47 \%$ of the examined children was found to be significantly less common than the homozygous genotype $C C(P<0.05)$ and the heterozygous genotype CT $(P<0.05)$.

2. Among the children of the Group I, the homozygous genotype TT was found in $15.09 \%$, the genotype CC in $37.47 \%$ and the heterozygous genotype in $47.17 \%$. Among children of the Group II, the genotype was found $18 \%$, the genotype CC and CT in $38.96 \%$ and $42.86 \%$. Among the children of the Group III, the genotype CC was found in $52.50 \%$ of children, the genotype CT in $32.50 \%$ and the genotype TT in $15.00 \%$.

3. The lesions of the nervous system with seizures in the medical history were most commonly reported in children with the TT genotype $(16.45 \%, P<0.05)$, while patients with the CC genotype had seizures in only $5.6 \%$ of cases. On the basis thereof, it can be assumed that the $\mathrm{C}$ allele and the $\mathrm{CC}$ genotype had a protective effect in the CNS lesions in the perinatal period of the examined children.

4. Children with a birth weight of 1500-1999 g, with a C/T heterozygous genotype and a T/T homozygous genotype of polymorphism of the FADS2 gene (rs1745683) had a lower total points on the Apgar scale than children with a birth weight of more than $2000 \mathrm{~g}(P<0.05)$. Moreover, in homozygotes for T allele, the total points were lower than in heterozygotes. In children, homozygous for $\mathrm{C}$ allele, there was no significant difference in the total points on the Apgar scale.

5. In children of groups I and II with the C/C genotype, the neurological symptoms of "pulling the child's heel to the ear", "abdominal suspension of the newborn" were within $1.0(1.0 ; 3.0)$ and $3.0(1,0 ; 3.0), P<0.05$. Also, children of group III $(3.0(2.5 ; 3.0)$ on the basis of the neurological symptoms of "abdominal suspension of a newborn" had significantly higher rates than children of group I. Among the heterozygotes with $\mathrm{C} / \mathrm{T}$ genotype of polymorphism of the FADS2 gene (rs1745683), the children of the group I $(1.0(0 ; 3.0)$ had significantly lower number of points than children of the group III $(3.0(1.0 ; 3.0))$ on the basis of such neurological symptoms as "posture", "square window". Among the homozygotes with T/T genotype, a significant difference between the total points in children of groups I and II was registered by neurological symptoms: "pulling the child's heel to the ear", "abdominal suspension of the newborn", in children of groups I and III - "flexion of the foot", "popliteal angle"; in children of groups II and III "abdominal suspension of the newborn".

6. The coefficient of psychomotor development was the lowest in children with birth weight of 1500-1999 g and a minor T/T homozygous genotype of the FADS2 gene (rs1745683) and made 83.0 (75.0; 83.0), which corresponded to a weak normal level of the neuropsychiatric development, while the highest index of psychomotor development $(116.0(112.0 ; 141.0))$ and a normal high level of neuropsychiatric development were significantly registered in children with birth weight of $2500 \mathrm{~g}$ and major $\mathrm{C} / \mathrm{T}$ homozygous genotype.

Prospects for further studies. We're planning to study the influence of the polymorphism of FADS2 gene (rs174583) on bone mineral density.

Conflicts of interest: authors have no conflict of interest to declare. Конфлікт інтересів: віАсутній.

Надійшла Ао редакції / Received: 11.02.2019

Після Аоопрацювання / Revised: 23.01.2020

Прийнято Ао Аруку / Accepted: 10.03.2020

Information about the authors:

Shumna T. Ye., MD, PhD, DSc, Professor of the Department of Faculty Pediatrics, Zaporizhzhia State Medical University, Ukraine. Levchuk-Vorontsova T. O., MD, Assistant of the Department of Faculty Pediatrics, Zaporizhzhia State Medical University, Ukraine.

Відомості про авторів:

Шумна Т. Є., А-р меА. наук, професор каф. факультетської пеАіатрії, Запорізький Аержавний медичний університет, Україна. 
Левчук-Воронцова Т. О., асистент каф. Аитячих хвороб, Запорізький державний медичний університет, Україна

\section{Сведения об авторах:}

Шумная Т. Е., А-р меА. наук, профессор каф. факультетской педиатрии, Запорожский государственный медицинский университет, Украина

левчук-Воронцова Т. О., ассистент каф. Аетских болезней, Запорожский государственный меАицинский университет, Украина.

\section{References}

[1] Liu, L., Oza, S., Hogan, D., Chu, Y., Perin, J., Zhu, J., Lawn, J. E., Cousens, S., Mathers, C., \& Black, R. E. (2016). Global, regional, and national causes of under-5 mortality in 2000-15: an updated systematic analysis with implications for the Sustainable Development Goals. The Lancet, 388(10063), 3027-3035. https://doi.org/10.1016 s0140-6736(16)31593-8

[2] Kvashnina, L., \& Matvienko, I. (2018). Peredchasni polohy: epidemiolohiia ta prychyn [Previous pologs: epidemiology and causes]. Slovo o zdorov'e, (1), 36-41. [in Ukrainian].

[3] Dyak, K. V., \& Yuzko, O. M. (2017). Prychynni faktory peredchasnykh polohiv (novyi pohliad na problemu) [Causative factors of premature birth (a new look at the problem)]. Neonatolohiia, khirurhiia ta perynatalna medytsyna, 7(1), 62-68. https://doi.org/10.24061/2413-4260. vii.1.23.2017.11 [in Ukrainian].

[4] World Health Organization. (2018, February 19). Preterm birth. https:// www.who.int/news-room/fact-sheets/detail/preterm-birth

[5] Howson, C. P., Kinney, M. V., Lawn, J. E., \& World Health Organization. (2012). Born Too Soon: The Global action report on preterm Birth. WHO Press. https://apps.who.int/iris/bitstream/handle/10665/44864/9789241503433 eng.pdf?sequence=1

[6] Gomez-Sanchez, C. I., Riveiro-Alvarez, R., Soto-Insuga, V., Rodrigo, M., Tirado-Requero, P., Mahillo-Fernandez, I., Abad-Santos, F. Carballo, J. J., Dal-Ré, R., \& Ayuso, C. (2015). Attention deficit hyperactivity disorder: genetic association study in a cohort of Spanish children. Behavioral and Brain Functions, 12(1), Article 2. https://doi. org/10.1186/s12993-015-0084-6

[7] Malinowska, M. A., Wiśniewski, O. W., \& Warchoł, M. (2017). Single nucleotide polymorphisms in desaturases genes - effect on docosahexaenoic acid levels in maternal and fetal tissues and early development of the child. Journal of Medical Science, 86(2), 177-185. https://doi. org/10.20883/ims.2016.237

[8] Nettleton, J. A., \& Salem, Jr. N. (2019). International Society for the Study of Fatty Acids and Lipids 2018 Symposium: Arachidonic and Docosahexaenoic Acids in Infant Development. Annals of Nutrition \& Metabolism, 74(1), 83-91. https://doi.org/10.1159/000495906

[9] Watson, C. L., Harrison, M. E., Hennes, J. E., \& Harris, M. M. (2016). «Revealing The Space Between»: Creating an Observation Scale to Understand Infant Mental Health Reflective Supervision. ZERO TO THREE, 37(2), 14-21. https://eric.ed.gov/?id=EJ1123774

[10] Heberden, C., \& Maximin, E. (2017). Epigenetic Effects of N-3 Polyunsaturated Fatty Acids. In V. Patel, V. Preedy (Eds.), Handbook of Nutrition, Diet, and Epigenetics (pp. 1-15). Springer, Cham. https:// doi.org/10.1007/978-3-319-31143-2 45-1

[11] Bar, S., Milanaik, R., \& Adesman, A. (2016). Long-term neurodevelopmental benefits of breastfeeding. Current Opinion in Pediatrics, 28(4), 559-566. https://doi.org/10.1097/MOP.0000000000000389

[12] Agostoni, C., Mazzocchi, A., Leone, L., Ciappolino, V., Delvecchio, G. Altamura, C. A., \& Brambilla, P. (2017). The first model of keeping energy balance and optimal psycho affective development: Breastfed infants. Journal of Affective Disorders, 224, 10-15. https://doi org/10.1016/i.jad.2017.01.001

[13] Lauritzen, L., Brambilla, P., Mazzocchi, A., Harsløf, L. B., Ciappolino, V., \& Agostoni, C. (2016). DHA Effects in Brain Development and Function. Nutrients, 8(1), Article 6. https://doi.org/10.3390/nu8010006

[14] Garg, P., Pejaver, R. K., Sukhija, M., \& Ahuja, A. (2017). Role of DHA ARA, \& phospholipids in brain development: An Indian perspective. Clinical Epidemiology and Global Health, 5(4), 155-162. https://doi. org/10.1016/j.cegh.2017.09.003

[15] Carlson, S. E., \& Colombo, J. (2016). Docosahexaenoic Acid and Arachidonic Acid Nutrition in Early Development. Advances in Pediatrics, 63(1), 453-471. https://doi.org/10.1016/i.yapd.2016.04.011

[16] Wang, S., Chen, J., Jiang, D., Zhang, Q., You, C., Tocher, D. R., Monroig, O.., Dong, Y., \& Li, Y. (2018). Hnf4a is involved in the regulation of vertebrate LC-PUFA biosynthesis: insights into the regulatory role of Hnf4a on expression of liver fatty acyl desaturases in the marine teleost Siganus canaliculatus. Fish Physiology and Biochemistry, 44(3), 805-815. https://doi.org/10.1007/s10695-018-0470-8
[17] Smith, S. L., \& Rouse, C. A. (2017). Docosahexaenoic acid and the preterm infant. Maternal Health, Neonatology and Perinatology, 3 Article 22. https://doi.org/10.1186/s40748-017-0061-1

[18] Meldrum, S. J., Li, Y., Zhang, G., Heaton, A., D’Vaz, N., Manz, J. Reischl, E., Koletzko, B. V., Prescott, S. L., \& Simmer, K. (2018). Can polymorphisms in the fatty acid desaturase (FADS) gene cluster alter the effects of fish oil supplementation on plasma and erythrocyte fatty acid profiles? An exploratory study. European Journal of Nutrition, 57(7) 2583-2594. https://doi.org/10.1007/s00394-017-1529-5

[19] Lee, S., Lee, J., Choi, I. J., Kim, Y. W., Ryu, K. W., Kim, Y. I., \& Kim, J. (2018). Dietary n-3 and n-6 polyunsaturated fatty acids, the FADS gene, and the risk of gastric cancer in a Korean population. Scientific Reports, 8(1), Article 3823. https://doi.org/10.1038/s41598-018-21960-3

[20] Peters, B. D., Voineskos, A. N., Szeszko, P. R., Lett, T. A., DeRosse, P., Guha, S., Karlsgodt, K. H., Ikuta, T., Felsky, D., John, M. Rotenberg, D. J., Kennedy, J. L., Lencz, T., \& Malhotra, A. K. (2014). Brain white matter development is associated with a human-specific haplotype increasing the synthesis of long chain fatty acids. The Journal of Neuroscience, 34(18), 6367-6376. https://doi.org/10.1523/ JNEUROSCI.2818-13.2014

[21] Makarova, S. G., \& Vishnyova, Ye. A. (2015). Sovremennye predstavleniya o vliyanii dlinnotsepochechnykh polinenasyshchennykh zhirnykh kislot na razvitie nervnoi sistemy u detei [Modern Views on the Impact of Long-Chain Polyunsaturated Fatty Acids on the Development of the Child's Nervous System]. Voprosy sovremennoi pediatrii, 14(1) 55-63. [in Russian].

[22] He, Z., Zhang, R., Jiang, F., Zhang, H., Zhao, A., Xu, B., Jin, L. Wang, T., Jia, W., Jia, W., \& Hu, C. (2018). FADS1-FADS2 genetic polymorphisms are associated with fatty acid metabolism through changes in DNA methylation and gene expression. Clinical Epigenetics, 10(1), Article 113. https://doi.org/10.1186/s13148-018-0545-5

[23] Reynolds, L. M., Howard, T. D., Ruczinski, I., Kanchan, K., Seeds, M. C. Mathias, R. A., \& Chilton, F. H. (2018). Tissue-specific impact of FADS cluster variants on FADS1 and FADS2 gene expression. PLOS ONE, 13(3), Article e0194610. https://doi.org/10.1371/journal.pone.0194610

[24] Sosa-Castillo, E., Rodríguez-Cruz, M., \& Moltó-Puigmartí, C. (2017) Genomics of lactation: role of nutrigenomics and nutrigenetics in the fatty acid composition of human milk. The British Journal of Nutrition, 118(3), 161-168. https://doi.org/10.1017/S0007114517001854

[25] AbuMweis, S. S., Panchal, S. K., \& Jones, P. (2018). Triacylglycerol-Lowering Effect of Docosahexaenoic Acid Is Not Influenced by Single-Nucleotide Polymorphisms Involved in Lipid Metabolism in Humans. Lipids, 53(9), 897-908. https://doi.org/10.1002/lipd.12096

[26] de la Garza Puentes, A., Montes Goyanes, R., Chisaguano Tonato, A. M., Torres-Espínola, F. J., Arias García, M., de Almeida, L., Bonilla Aguirre, M., Guerendiain, M., Castellote Bargalló, A. I., Segura Moreno, M., García-Valdés, L., Campoy, C., Lopez-Sabater, M. C., \& PREOBE team. (2017). Association of maternal weight with FADS and ELOVL genetic variants and fatty acid levels- The PREOBE follow-up. PLOS ONE, 12(6), Article e0179135. https://doi.org/10.1371/journal. pone. 0179135

27] Barman, M., Nilsson, S., Torinsson Naluai, A. Sandin, A. Wold, A. E \& Sandberg, A. S. (2015). Single Nucleotide Polymorphisms in the FADS Gene Cluster but not the ELOVL2 Gene are Associated with Serum Polyunsaturated Fatty Acid Composition and Development of Allergy (in a Swedish Birth Cohort). Nutrients, 7(12), 10100-10115. https://doi. org/10.3390/nu7125521

[28] Gonzalez-Casanova, I., Rzehak, P., Stein, A. D., Garcia Feregrino, R. Rivera Dommarco, J. A., Barraza-Villarreal, A., Demmelmair, H. Romieu, I., Villalpando, S., Martorell, R., Koletzko, B., \& Ramakrishnan, U. (2016). Maternal single nucleotide polymorphisms in the fatty acid desaturase 1 and 2 coding regions modify the impact of prenatal supplementation with DHA on birth weight. The American Journa of Clinical Nutrition, 103(4), 1171-1178. https://doi.org/10.3945/ aicn.115.121244

[29] Yeates, A. J., Love, T. M., Engström, K., Mulhern, M. S., McSorley, E. M., Grzesik, K., Alhamdow, A., Wahlberg, K., Thurston, S. W. Davidson, P. W., van Wijngaarden, E., Watson, G. E., Shamlaye, C. F. Myers, G. J., Strain, J. J., \& Broberg, K. (2015). Genetic variation in FADS genes is associated with maternal long-chain PUFA status but not with cognitive development of infants in a high fish-eating observationa study. Prostaglandins, Leukotrienes \& Essential Fatty Acids, 102, 13-20. https://doi.org/10.1016/j.plefa.2015.08.004

[30] Goldenberg, R. L., Cliver, S. P., Mulvihill, F. X., Hickey, C. A., Hoffman, H. J., Klerman, L. V., \& Johnson, M. J. (1996). Medical, psychosocial, and behavioral risk factors do not explain the increased risk for low birth weight among black women. American Journal of Obstetrics \& Gynecology, 175(5), 1317-1324. https://doi.org/10.1016 s0002-9378(96)70048-0

[31] Ensembl. (n.d.). Population genetics - Homo sapiens - Ensembl genome browser 100. Ensembl.org. Retrieved June 5, 2020. http://www. ensembl.org/Homo sapiens/Variation/Population?db=core 
[32] Ameur, A., Enroth, S., Johansson, A., Zaboli, G., Igl, W., Johansson, A. C., Rivas, M. A., Daly, M. J., Schmitz, G., Hicks, A. A., Meitinger, T., Feuk, L., van Duijn, C., Oostra, B., Pramstaller, P. P., Rudan, I., Wright, A. F., Wilson, J. F., Campbell, H., \& Gyllensten, U. (2012). Genetic adaptation of fatty-acid metabolism: a human-specific haplotype increasing the biosynthesis of long-chain omega- 3 and omega- 6 fatty acids. American Journal of Human Genetics, 90(5), 809-820. https:/l doi.org/10.1016/j.ajhg.2012.03.014

[33] Martin, N. W., Benyamin, B., Hansell, N. K., Montgomery, G. W., Martin, N. G., Wright, M. J., \& Bates, T. C. (2011). Cognitive function in adolescence: testing for interactions between breast-feeding and FADS2 polymorphisms. Journal of the American Academy of Child \& Adolescent Psychiatry, 50(1), 55-62.e4. https://doi.org/10.1016/j. jaac.2010.10.010

[34] Martinez, M., \& Vazquez, E. (1998). MRI evidence that docosahexaenoic acid ethyl ester improves myelination in generalized peroxisomal disorders. Neurology, 51(1), 26-32. https://doi.org/10.1212/wnl.51.1.26

[35] Uauy, R., \& Mena, P. (2015). Long-chain polyunsaturated fatty acids supplementation in preterm infants. Current Opinion in Pediatrics, 27(2), 165-171. https://doi.org/10.1097/MOP.0000000000000203

[36] Tam, E. W., Chau, V., Barkovich, A. J., Ferriero, D. M., Miller, S. P., Rogers, E. E., Grunau, R. E., Synnes, A. R., Xu, D., Foong, J., Brant, R., \& Innis, S. M. (2016). Early postnatal docosahexaenoic acid levels and improved preterm brain development. Pediatric Research, 79(5), 723-730. https://doi.org/10.1038/pr.2016.11

[37] Plunkett, B. A. (2019). 310: Association of breastfeeding (BF) and IQ. American Journal of Obstetrics and Gynecology, 220(1), S217-S218. https://doi.org/10.1016/i.ajog.2018.11.331

[38] Boutwell, B. B., Young, J., \& Meldrum, R. C. (2018). On the positive relationship between breastfeeding \& intelligence. Developmental Psychology, 54(8), 1426-1433. https://doi.org/10.1037/dev0000537

[39] Siziba, L. P., Baumgartner, J., Rothman, M., Matsungo, T. M., Faber, M., \& Smuts, C. M. (2020). Efficacy of novel small-quantity lipid-based nutrient supplements in improving long-chain polyunsaturated fatty acid status of South African infants: a randomised controlled trial. European Journal of Clinical Nutrition, 74(1), 193-202. https://doi.org/10.1038/ s41430-019-0482-1

[40] Zielinska, M. A., Hamulka, J., Grabowicz-Chądrzyńska, I., Bryś, J., \& Wesolowska, A. (2019). Association between Breastmilk LC PUFA, Carotenoids and Psychomotor Development of Exclusively Breastfed Infants. International Journal of Environmental Research and Public Health, 16(7), 1144. https://doi.org/10.3390/ijerph16071144

[41] Vasyutin, K. A. (2009). Sostoyanie zdorov'ya detei pervogo goda zhizni, nakhodyashchikhsya na razlichnykh vidakh vskarmlivaniya [Children health in the first year of life within various feeding practices]. Vyatskii meditsinskii vestnik, (1), 62. [in Russian].

[42] Babayeva, L. A., \& Gafurjanova, H. A. (2015). Otsenka nervno-psikhicheskogo razvitiya detei grudnogo vozrasta v zavisimosti ot vida vskarmlivaniya [Evaluation of neuropsychic development of infants depending on the feeding type]. Vestnik Avitsenny, (4), 104-107. [in Russian].

[43] Nefedeva, D. L., \& Bodrova, R. A. (2015). Opredelenie reabilitatsionnogo potentsiala u nedonoshennykh detei na osnove mezhdunarodnoi klassifikatsii funktsionirovaniya, ogranichenii zhiznedeyatel'nosti i zdorov'ya (MKF) [levaluation of rehabilitation potential of premature children on the basis of international classification of functioning, disability and health]. Vestnik vosstanovitel'noi meditsiny, (6), 2-9. [in Russian].

[44] Ivanov, D. O., Kozlova, L. V., \& Derevtsov, V. V. (2017). Nervno-psikhicheskoe razvitie u detei, imevshikh vnutriutrobnuyu zaderzhku rosta, $\checkmark$ pervom polugodii zhizni [Neuropsychiatric development of children in the first 6 months of life born with fetus growth delay]. Pediatr, 8(1), 40-49. https://doi.org/10.17816/PED8140-49 [in Russian].

[45] Monteith, C., Flood, K., Pinnamaneni, R., Levine, T. A., Alderdice, F. A., Unterscheider, J., McAuliffe, F. M., Dicker, P., Tully, E. C., Malone, F. D., \& Foran, A. (2019). An abnormal cerebroplacental ratio (CPR) is predictive of early childhood delayed neurodevelopment in the setting of fetal growth restriction. American Journal of Obstetrics and Gynecology, 221(3), 273.e1-273.e9. https://doi.org/10.1016/j. ajog.2019.06.026

[46] Adams-Chapman, I., Heyne, R. J., DeMauro, S. B., Duncan, A. F., Hintz, S. R., Pappas, A., Vohr, B. R., McDonald, S. A., Das, A., Newman, J. E., Higgins, R. D., \& Follow-Up Study of the Eunice Kennedy Shriver National Institute of Child Health and Human Development Neonatal Research Network. (2018). Neurodevelopmental Impairment Among Extremely Preterm Infants in the Neonatal Research Network. Pediatrics, 141(5), Article e20173091. https://doi.org/10.1542/ peds.2017-3091

[47] Marques, R. C. Dórea, J. G., Cunha, M., Bello, T., Bernardi, J., \& Malm, O. (2019). Data relating to maternal fish consumption, methylmercury exposure, and early child neurodevelopment in the traditional living of Western Amazonians. Data in brief, 25, Article 04153. https:// doi.org/10.1016/j.dib.2019.104153 